\title{
Estrogen receptor-beta sensitizes breast cancer cells to the anti-estrogenic actions of endoxifen
}

\author{
Xianglin Wu', Malayannan Subramaniam', Sarah B Grygo ${ }^{1}$, Zhifu Sun², Vivian Negron³ , Wilma L Lingle ${ }^{3}$, \\ Matthew P Goetz ${ }^{4}$, James N Ingle ${ }^{4}$, Thomas C Spelsberg ${ }^{1}$ and John R Hawse ${ }^{1^{*}}$
}

\begin{abstract}
Introduction: We have previously demonstrated that endoxifen is the most important tamoxifen metabolite responsible for eliciting the anti-estrogenic effects of this drug in breast cancer cells expressing estrogen receptoralpha (ERa). However, the relevance of ER $\beta$ in mediating endoxifen action has yet to be explored. Here, we characterize the molecular actions of endoxifen in breast cancer cells expressing ER $\beta$ and examine its effectiveness as an anti-estrogenic agent in these cell lines.
\end{abstract}

Methods: MCF7, Hs578T and U2OS cells were stably transfected with full-length ERß. ERß protein stability, dimer formation with ERa and expression of known ER target genes were characterized following endoxifen exposure. The ability of various endoxifen concentrations to block estrogen-induced proliferation of MCF7 parental and ERBexpressing cells was determined. The global gene expression profiles of these two cell lines was monitored following estrogen and endoxifen exposure and biological pathway analysis of these data sets was conducted to identify altered cellular processes.

Results: Our data demonstrate that endoxifen stabilizes ER $\beta$ protein, unlike its targeted degradation of ERa, and induces $E R a / E R \beta$ heterodimerization in a concentration dependent manner. Endoxifen is also shown to be a more potent inhibitor of estrogen target genes when ER $\beta$ is expressed. Additionally, low concentrations of endoxifen observed in tamoxifen treated patients with deficient CYP2D6 activity (20 to $40 \mathrm{nM}$ ) markedly inhibit estrogeninduced cell proliferation rates in the presence of ER $\beta$, whereas much higher endoxifen concentrations are needed when ER $\beta$ is absent. Microarray analyses reveal substantial differences in the global gene expression profiles induced by endoxifen at low concentrations ( $40 \mathrm{nM}$ ) when comparing MCF7 cells which express ER $\beta$ to those that do not. These profiles implicate pathways related to cell proliferation and apoptosis in mediating endoxifen effectiveness at these lower concentrations.

Conclusions: Taken together, these data demonstrate that the presence of ER $\beta$ enhances the sensitivity of breast cancer cells to the anti-estrogenic effects of endoxifen likely through the molecular actions of ERa/ $\beta$ heterodimers. These findings underscore the need to further elucidate the role of ER $\beta$ in the biology and treatment of breast cancer and suggest that the importance of pharmacologic variation in endoxifen concentrations may differ according to $E R \beta$ expression.

\section{Introduction}

Each year, nearly 1.3 million women are diagnosed with breast cancer worldwide and about two-thirds of these individuals are determined to have hormone sensitive tumors based on the expression of estrogen receptoralpha $(E R \alpha)$. Tamoxifen, a selective estrogen receptor

\footnotetext{
* Correspondence: hawse.john@mayo.edu

'Department of Biochemistry and Molecular Biology, Mayo Clinic, 200

1stStreet SW, Rochester, MN 55905, USA

Full list of author information is available at the end of the article
}

modulator (SERM), remains an important therapeutic agent in the treatment of women with endocrine sensitive breast cancer as it is known to effectively inhibit the proliferation-inducing effects of $17 \beta$-estradiol (estrogen) in ER $\alpha$ positive breast tumor cells.

Like many drugs, tamoxifen is extensively metabolized in the body by the cytochrome P450 enzyme system resulting in the production of three primary metabolites; 4-hydroxytamoxifen (4HT), N-desmethyl-tamoxifen (NDT) and endoxifen [1-3]. Recent reports have 
demonstrated that steady state circulating levels of tamoxifen, 4HT, and NDT in women receiving the standard dose of tamoxifen therapy (20 mg/day) are $300 \mathrm{nM}, 7 \mathrm{nM}$, and $700 \mathrm{nM}$, respectively [4]. However, plasma endoxifen concentrations are highly variable, ranging from 5 to $180 \mathrm{nM}$, due to the activity of the cytochrome P450 2D6 (CYP2D6) mediated oxidation of NDT [3]. Prospective studies have demonstrated that genetic CYP2D6 polymorphisms, and drugs, which reduce or abrogate CYP2D6 enzyme activity, significantly decrease endoxifen plasma concentrations [3-5]. These findings encouraged investigators to examine the hypothesis that CYP2D6 genotype status, and thus endoxifen concentrations, would affect clinical outcome in women treated with tamoxifen for their breast cancer. Although some controversy remains, the majority of the reports indicate a relationship between CYP2D6-related low levels of endoxifen and poor outcomes [6-15]. Past studies from this laboratory support these clinical findings as we have demonstrated that endoxifen is the most potent tamoxifen metabolite responsible for inhibiting estrogen induced gene expression changes and proliferation rates in ER $\alpha$ positive breast cancer cells at clinically relevant concentrations [16]. At this time, the clinical development of endoxifen is ongoing, with $\mathrm{NCI}$ supported phase I studies of endoxifen hydrochloride set to commence in early 2011 at both the Mayo Clinic and NCI.

Tamoxifen and its metabolites are known to function by blocking the effects of estrogen, a steroid hormone that binds to, and activates, two main ER isoforms, ER $\alpha$ and ER $\beta$. The role of ER $\alpha$ in breast cancer has been studied extensively for years, and its protein expression remains the most important biomarker in the treatment of this disease. However, the potential functions of ER $\beta$ in the progression and treatment of breast cancer have largely remained a mystery. In vitro studies have revealed that the actions of these two receptors are drastically different at the level of gene expression, both in response to estrogen and anti-estrogens [17-23]. Numerous reports have demonstrated that exposure of ER $\alpha$ expressing breast cancer cells to estrogen results in increased rates of proliferation while more recent studies have suggested that expression of ER $\beta$ alone $[21,24,25]$, or in combination with ER $\alpha$ [26-28], inhibits cell proliferation following estrogen exposure.

The summation of these in vitro studies suggests that ER $\beta$ may function as a tumor suppressor. A number of clinical studies have revealed that the presence of ER $\beta$ protein in breast tumors correlates with improved rates of recurrence, disease-free survival and overall survival [29-38] while others indicate little correlation [39-41] or even worse prognosis $[42,43]$. Additional studies have suggested that the expression of $\operatorname{ER} \beta$ in breast tumors increases the effectiveness of tamoxifen therapy [44-46] and one report found that $47 \%$ of breast tumors classified as ER $\alpha$ negative express ER $\beta$ [33]. These observations highlight the need to further define the relevance of ER $\beta$ in breast cancer progression and treatment.

Based on the foregoing, the objective of the present study was to determine the role of ER $\beta$ in mediating endoxifen action in breast cancer cells. The results of this study demonstrate that ER $\beta$ enhances the antiestrogenic effects of endoxifen in breast cancer cells likely through the actions of ER $\alpha / \beta$ heterodimers, and suggest that the achievement of higher endoxifen concentration may not be necessary in patients whose tumors express ER $\beta$ and that these same patients may benefit from tamoxifen therapy regardless of their CYP2D6 genotype.

\section{Materials and methods \\ Cell culture, chemicals and reagents}

MCF7 cells were generously provided by Dr. Robert Clarke (Georgetown University) and were cultured in phenol red-free Dulbecco's modified Eagle's medium/ F12 (DMEM/F12) medium containing 10\% (v/v) fetal bovine serum (FBS) and 1\% (v/v) antibiotic-antimycotic (AA) solution in a humidified $37^{\circ} \mathrm{C}$ incubator with $5 \%$ $\mathrm{CO}_{2}$. MCF7 cells stably expressing ER $\beta$ were generated using an S-tagged-Flag-tagged ER $\beta$ expression construct (pIRES2-EGFP) developed in our laboratory. Individual MCF7-ER $\beta$ clones were isolated following selection with $300 \mu \mathrm{L} / \mathrm{mL}$ G418. Doxycycline inducible Hs578T-ER $\beta$, U2OS-ER $\beta$ and U2OS-ER $\alpha / \beta$ cells lines were cultured as previously described [19-21]. All cell treatments were conducted in phenol red-free DMEM/F12 medium containing $10 \%$ triple charcoal stripped FBS. 17 $\beta$-estradiol and doxycyline were purchased from Sigma Aldrich (St. Louis, MO, USA). PPT (propyl pyrazole triol) and DPN (diarylpropionitrile) were purchased from Tocris Biosciences Inc. (Baldwin, MO, USA). (Z)-endoxifen was synthesized by Dr. Abdul Fauq (Mayo Clinic, Jacksonville, FL, USA).

\section{Antibodies}

The polyclonal ER $\beta$ specific antibody utilized in this study was developed by this laboratory. Briefly, a protein fragment of ER $\beta$ spanning amino acids 1 to 140 was cloned into the pGEX-5X-3 vector (Life Technologies, Carlsbad, CA, USA) and expressed in DH5 $\alpha$ bacterial cells. Purified ER $\beta$ protein was immunized in rabbits by Cocalico Biologicals Inc (Reamstown, PA, USA). ER $\beta$ specific antibodies were purified from serum using an affinity purification column containing the ER $\beta$ protein fragment. We have extensively characterized this antibody through Western blotting, immunoprecipitation, immunohistochemistry and immunoflourescence using 
multiple cell model systems which express either no ERs, ER $\alpha$ alone, ER $\beta$ alone or a combination of ER $\alpha$ and $E R \beta$, to ensure its specificity for the $\beta$ isoform. These data have revealed that this antibody is highly sensitive for the detection of ER $\beta$ and exhibits no crossreaction with $E R \alpha$ or other proteins (data not shown). $\mathrm{ER} \alpha$ (H-20) antibody was purchased from Santa Cruz Biotechnology (Santa Cruz, CA, USA). Flag (M2) and $\alpha$-Tubulin (DM 1A) antibodies were purchased from Sigma Aldrich.

\section{Western blotting}

All cell lysates were harvested using NETN buffer (150 mM NaCl, $1 \mathrm{mM}$ EDTA, $20 \mathrm{mM}$ Tris (pH 8.0), $0.5 \%$ Nonidet $\mathrm{P}-40$ ) and insoluble material was pelleted. Protein concentrations were determined using Bradford Reagent and equal amounts of cell lysate were separated by SDS-PAGE. Proteins were transferred to PVDF membranes, probed with primary and secondary antibodies and visualized using enhanced chemiluminescence (Amersham Biosciences, Piscataway, NJ, USA).

\section{Immunofluorescent staining analysis}

MCF7-ER $\beta$ cells were plated on cover slides at approximately $50 \%$ confluence and fixed with cold methanol for one hour followed by permeabilization with $0.1 \%$ Triton $\mathrm{X}-100$ for five minutes on ice. Slides were pre-incubated in $5 \%$ goat serum for one hour followed by exposure to Flag antibody for another hour. Slides were washed three times with $1 \times$ PBS and subsequently incubated with Rhodamine-labeled anti-mouse secondary antibody (Sigma-Aldrich) for 30 minutes at room temperature. Nuclei were simultaneously stained with DAPI (SigmaAldrich). Immunofluorescent detection was conducted using a Zeiss Laser Scanning Microscope 510 (Carl Zeiss, Jena, Germany)

\section{Luciferase assays}

MCF7-ER $\beta$ cells were plated in 12-well tissue culture plates at approximately $70 \%$ confluence and subsequently transfected in triplicate with $250 \mathrm{ng}$ per well of the ERE-TK-luciferase reporter construct using Fugene 6 (Roche Applied Science, Indianapolis, IN, USA). Following transfection, cells were treated as indicated for $24 \mathrm{~h}$. Cells were lysed in 1× Passive Lysis Buffer (Promega, Madison, WI, USA) and equal amounts of extract were assayed for luciferase activity.

\section{Co-Immunoprecipitation assays}

MCF7-ER $\beta$ or U2OS-ER $\alpha / \beta$ cells were plated at a density of approximately $50 \%$ in $100 \mathrm{~mm}$ tissue culture plates. U2OS cells were treated with doxycycline as previously described to induce expression of ER $\alpha$ and ER $\beta$ [20] and subsequently exposed to indicated concentrations of endoxifen. Following 24 hours of incubation, cells were washed twice with PBS and lysed in NETN buffer. Equal amounts of cell lysates were immunoprecipitated at $4^{\circ} \mathrm{C}$ overnight using $1 \mu \mathrm{g}$ of either Flag or ER $\beta$ antibody. Protein complexes were purified using protein $G$ beads, separated by SDS-PAGE, transferred to PVDF membranes and blocked in 5\% milk overnight. Western blotting was performed using indicated antibodies as described above.

Real-time reverse transcriptase polymerase chain reaction MCF7 and MCF7-ER $\beta$ cells were plated in 12-well tissue-culture plates and treated in triplicate as indicated for 24 hours. Total RNA was isolated using Trizol reagent (Invitrogen) and $500 \mathrm{ng}$ was reverse transcribed using the iScript ${ }^{\mathrm{TM}}$ cDNA Synthesis Kit (Bio-Rad). Realtime PCR was performed in triplicate using a Bio-Rad iCycler (Hercules, CA, USA) and a PerfeCTa ${ }^{\mathrm{TM}}$ SYBR Green Fast Mix ${ }^{\mathrm{TM}}$ for iQ real-time PCR kit (Quanta Biosciences, Gaithersburg, MD, USA) as specified by the manufacturer. Quantitation of the PCR results were calculated based on the threshold cycle $\left(C_{t}\right)$ and were normalized using TATA Binding Protein as a control. All PCR primers were designed using Primer3 software [47] and were purchased from Integrated DNA Technologies (Coralville, IA, USA). Primer sequences are provided in Additional file 1.

\section{Cell proliferation assays}

MCF7 and MCF7-ER $\beta$ cells were grown in 10\% triple charcoal-stripped serum-containing medium for three days and subsequently plated at a density of 2,000 cells per well in 96-well tissue culture plates. Cells were treated with vehicle, $1 \mathrm{nM}$ estrogen or $1 \mathrm{nM}$ estrogen plus increasing concentrations of endoxifen (20 to 1,000 nM) for eight days. Culture medium and treatments were replaced every other day. Proliferation rates were determined using a CellTiter-Glo Luminescent Cell Viability kit (Promega).

\section{Illumina microarray analysis}

Changes in the gene expression profiles of MCF7 and MCF7-ER $\beta$ cells elicited by either $1 \mathrm{nM}$ estrogen alone or estrogen plus $40 \mathrm{nM}$ endoxifen were determined using the Illumina HumanHT-12 expression BeadChip platform to screen more than 27,000 annotated genes represented by 48,804 probes by Mayo Clinic's Advanced Genomics Technology Center (Rochester, MN, USA). Data were processed using BeadStudio Version 3.1 and normalized using the fastlo function [48] implemented in the statistical package R. Data were filtered to exclude probes (referred to as genes throughout) whose expression was at or below background levels as determined by detection $P$-values $(\geq 0.05)$. 
Pair-wise comparisons were made to identify differentially expressed genes using Linear Models for Microarray Data (LIMMA). Genes were determined to be significantly regulated if their differential $P$-value was $<0.05$ between groups. Fold changes were calculated by raising 2 to the power of mean difference (log 2 scale) between the treatment groups and controls. The normalized and raw microarray data presented here are available in the Gene Expression Omnibus [49] under the accession number: [GEO:GSE27375].

\section{Biological pathway analysis}

Genes determined to be significantly regulated by the addition of $40 \mathrm{nM}$ endoxifen relative to estrogen alone in both parental and ER $\beta$ expressing MCF7 cells were further analyzed using MetaCore software to identify differences in biological pathways altered between the two cell lines. Genes with differential expression $P$-values $<0.05$ from each comparison were used as focus genes and a hypergeometric test was applied to each of over 600 canonical pathways. Enriched pathways with $P$-values $<0.05$ were suggested to be significantly regulated by the addition of $40 \mathrm{nM}$ endoxifen within each cell line. Adjustment for multiple comparisons was conducted using a false discovery rate of 0.25 .

\section{Results}

Development and characterization of MCF7-ER $\beta$ cell lines In order to determine the effects of ER $\beta$ expression on the actions of endoxifen in breast cancer, we first developed MCF7 cell lines stably expressing this receptor. MCF7 cells were chosen for this study since they are the most well characterized ER $\alpha$ positive breast cancer cell line with regard to estrogen regulated gene expression and proliferation. As shown in Additional file 2, the parental MCF7 cell line used throughout this study was confirmed to be ER $\beta$ negative by both real-time PCR and Western blotting and these data are shown relative to the expression of ER $\beta$ mRNA and protein in one of our over-expressing cell lines. Multiple MCF7-ER $\beta$ clonal cell lines were developed by expressing $S$ and Flagtagged full-length ER $\beta$ followed by selection with G418. All cell lines were screened for ER $\beta$ protein expression by Western blotting and three representative lines are shown in Figure 1A relative to parental cells. While all of the data presented in Figures 1, 2, 3, 4 were confirmed in multiple MCF7-ER $\beta$ clones, the data collected from clone number 3 were chosen for representation in these figures due to its robust expression of ER $\beta$. Immunofluorescent staining using a flag antibody was utilized to verify ER $\beta$ positivity and cellular localization. The results demonstrate that ER $\beta$ is expressed and localized in the nucleus of MCF7-ER $\beta$ cells (Figure 1B). ER $\beta$ functionality was investigated using an estrogen

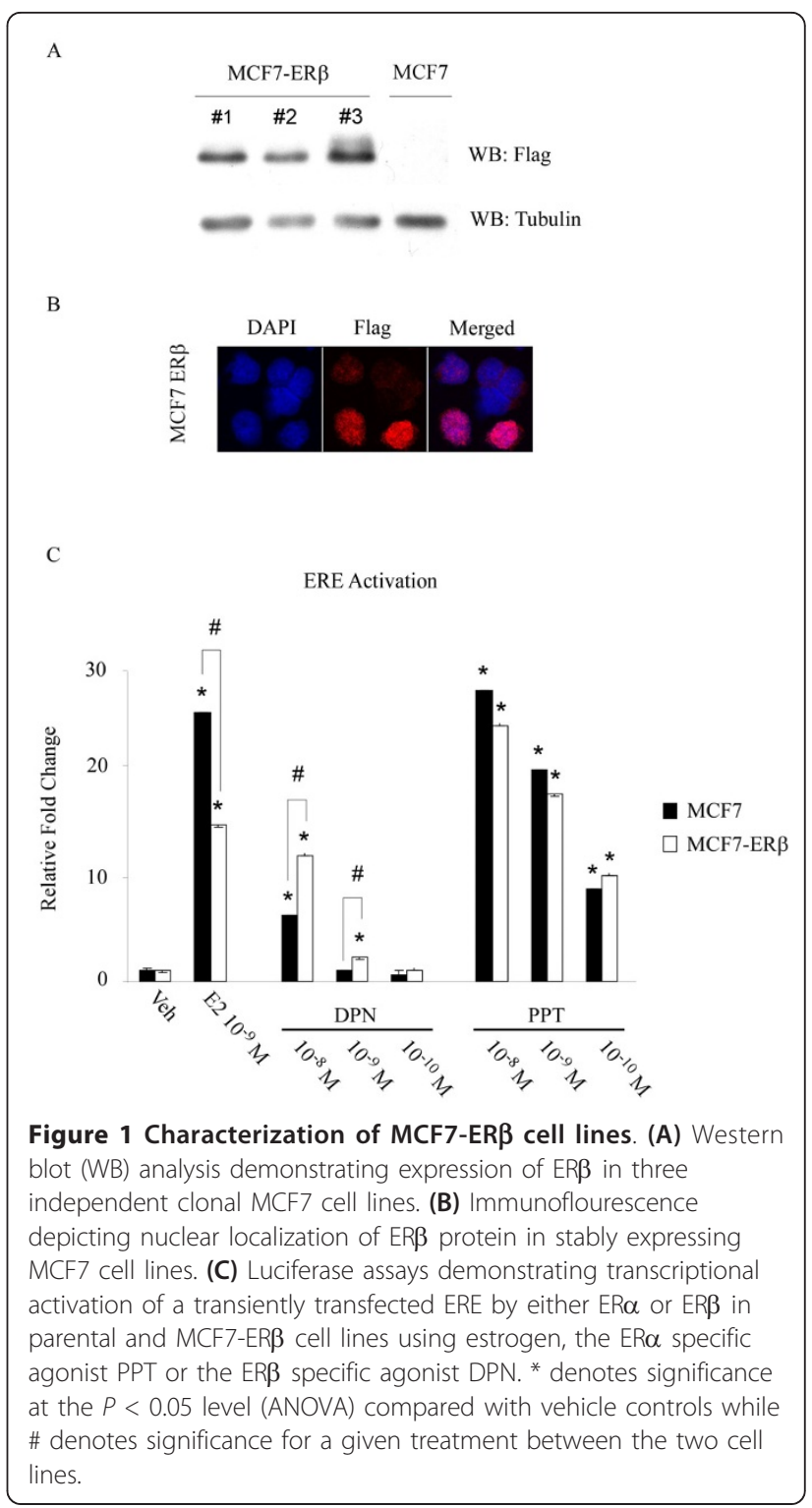

response element (ERE) transcriptional assay involving an ERE-TK-luciferase reporter construct. The construct was transfected into parental and ER $\beta$ expressing MCF7 cells followed by treatment with either estrogen, the ER $\alpha$ specific agonist PPT or the ER $\beta$ specific agonist DPN. As shown in Figure 1C, estrogen significantly induced ERE activity in both MCF7 parental and ER $\beta$ expressing cells. Interestingly, estrogen induction of the ERE was significantly lower in ER $\beta$ expressing cells possibly due to the reported inhibitory actions of ER $\beta$ on ER $\alpha$ transcriptional activity. The ER $\beta$ specific agonist, $\mathrm{DPN}$, resulted in significant activation of the ERE reporter construct in cells expressing ER $\beta$ (Figure 1C). ERE activation in parental MCF7 cells by $10^{-8} \mathrm{M} D P N$ is explained by its non-specific interactions with ER $\alpha$ at 


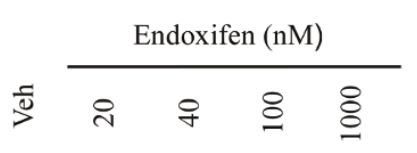

A

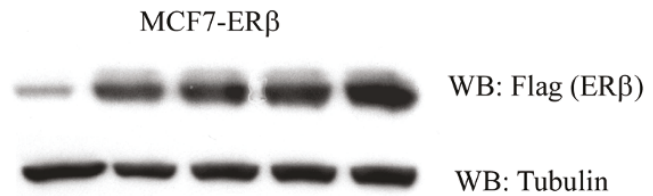

B

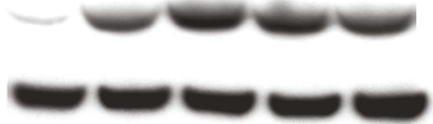

WB: Flag (ER $\beta)$

WB: Tubulin

C

U2OS-ER $\beta$

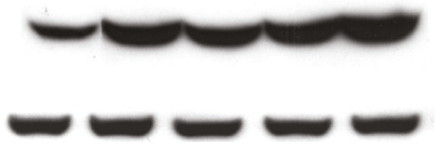

WB: Flag $(\mathrm{ER} \beta)$

WB: Tubulin

Figure 2 Stabilization of ER $\beta$ protein levels by endoxifen Western blot (WB) analysis of ERß protein levels in MCF7-ERß (A), Hs578T-ER $\beta$ (B) and U2OS-ER $\beta$ (C) cells treated with indicated concentrations of endoxifen or vehicle for 24 hours. Tubulin levels are shown as protein loading controls.

high concentrations [50]. As expected, all concentrations of the ER $\alpha$ specific ligand, PPT, resulted in identical ERE activation regardless of ER $\beta$ expression (Figure 1C). These data demonstrate that our newly developed MCF7-ER $\beta$ cell lines express intact and functional ER $\beta$ protein.

\section{ER $\beta$ protein levels are stabilized by endoxifen}

Since we have previously demonstrated that endoxifen exposure results in rapid turnover of $E R \alpha$ protein in multiple cell types through proteasomal degradation [16], it was of interest to determine the effects of endoxifen on ER $\beta$ protein levels. Unlike that of ER $\alpha$, endoxifen exposure resulted in stabilization of ER $\beta$ protein in MCF7-ER $\beta$ cells in a concentration dependent manner (Figure 2A). These results were confirmed in Hs578T breast cancer cells and U2OS osteosarcoma cells stably expressing ER $\beta$ (Figure 2B, C).

\section{Endoxifen induces $E R \alpha / \beta$ heterodimer formation}

Given that ER $\beta$ protein levels are stabilized by endoxifen and that ER $\beta$ interacts with ER $\alpha$, we next sought to determine if endoxifen exposure resulted in $E R \alpha / \beta$ heterodimer formation. Immunoprecipitation assays

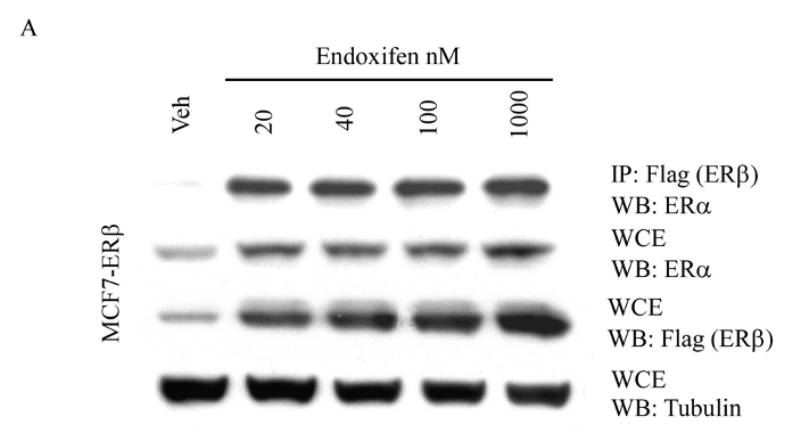

B

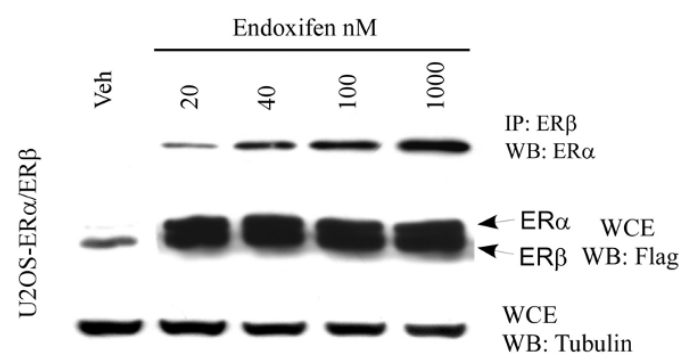

Figure 3 Endoxifen induces $E R \alpha / \beta$ heterodimer formation MCF7-ER $\beta$ (A) or U2OS-ER $\alpha / \beta$ (B) cells were treated with indicated concentrations of endoxifen or vehicle for 24 hours. Equal amounts of cell lysates were immunoprecipitated with an ERß specific antibody. Immunoprecipitated protein (IP) complexes were separated by SDS-PAGE and Western blotting (WB) was performed using an ER $\alpha$ specific antibody. Non-immunoprecipitated ER $\alpha$ and ER $\beta$ protein levels were also determined by Western blotting in whole cell extracts (WCE) following endoxifen treatment. Tubulin levels are shown as protein loading controls.

demonstrate that endoxifen induces $E R \alpha / \beta$ heterodimer formation in MCF7-ER $\beta$ cells which results in the stabilization and accumulation of ER $\alpha$ protein levels (Figure $3 \mathrm{~A})$. These studies were conducted in U2OS cells stably expressing both ER isoforms and similar results were observed (Figure 3B). The results of these studies demonstrate that exposure of cells which express both ER isoforms to endoxifen results in stabilization and accumulation of both ER $\alpha$ and ER $\beta$ protein likely due to its induction of heterodimer formation. It is speculated that ER $\alpha$ and ER $\beta$ homodimer formation likely occurs to some degree as well.

\section{Endoxifen's ability to inhibit estrogen induced gene expression and proliferation is enhanced by ER $\beta$} Our laboratory previously characterized the inhibition of estrogen induced gene expression and proliferation by endoxifen in MCF7 cells [16]. In order to determine the effects of ER $\beta$ expression on the anti-estrogenic actions of endoxifen, we next compared the ability of endoxifen to inhibit estrogen induction of known ER $\alpha$ target genes 


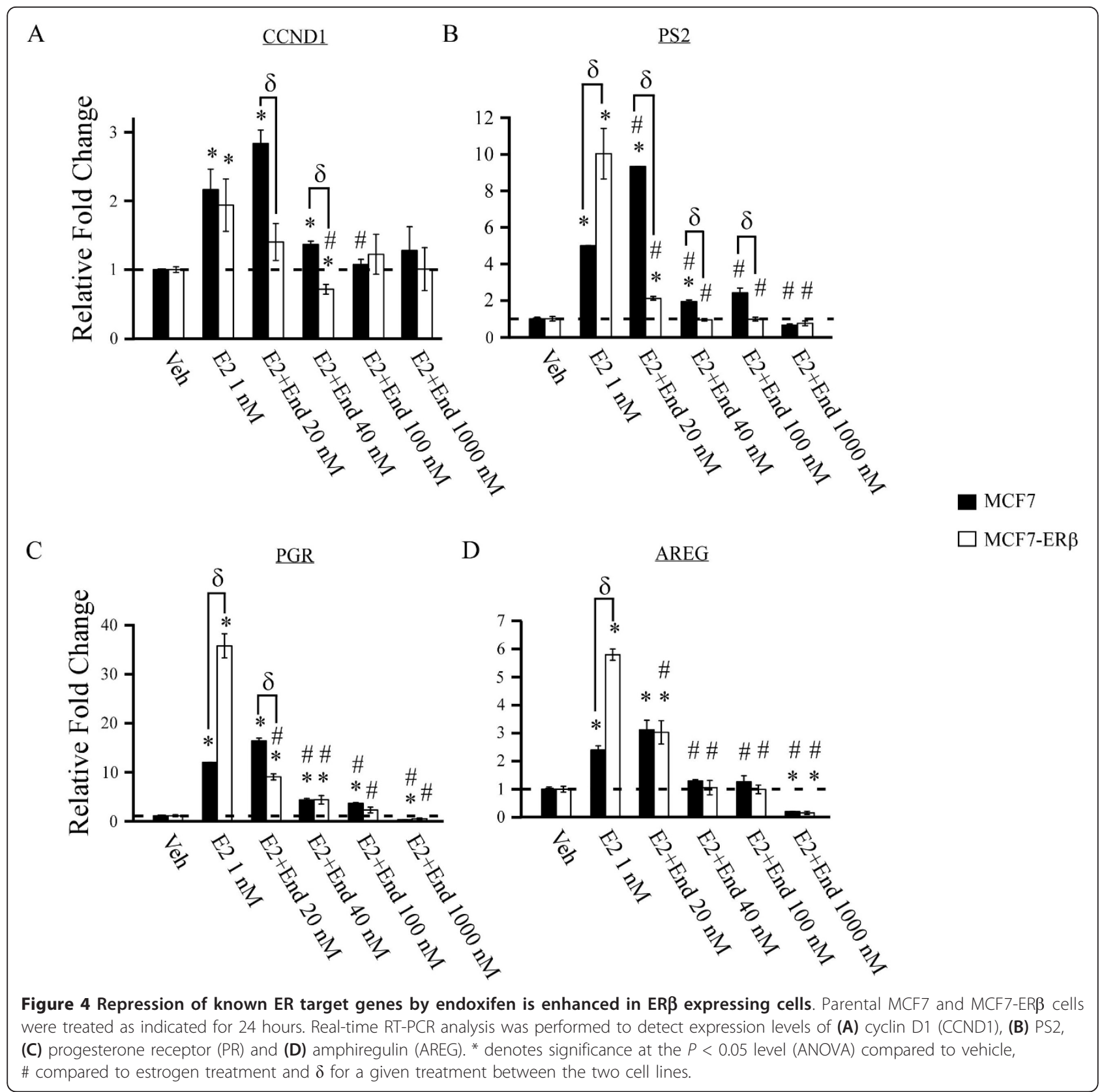

in parental and ER $\beta$ expressing MCF7 cells. The expression levels of cyclinD1, PS2, progesterone receptor and amphiregulin were monitored in both cell lines by realtime PCR following treatment with estrogen alone or estrogen plus increasing concentrations of endoxifen. In contrast to the ERE data presented in Figure 1, estrogen treatment further stimulated the expression of three of the four genes (PS2, PGR and AREG) in ER $\beta$ expressing cells relative to the parental cell line (Figure 4A-D). Interestingly, low concentrations of endoxifen (20 nM) significantly inhibited the estrogen induction of three of the four genes (CCND1, PS2 and PGR) only in ER $\beta$ expressing cells while higher endoxifen concentrations (100 to $1,000 \mathrm{nM}$ ) resulted in similar patterns of gene expression between the two cell lines (Figure 4A-D). These data suggest that expression of ER $\beta$, in ER $\alpha$ positive breast cancer cells, enhances the anti-estrogenic properties of endoxifen.

To confirm these data, and to determine if expression of ER $\beta$ enhances the ability of endoxifen to suppress estrogen induced cell growth, proliferation assays were performed. Two independent ER $\beta$ expressing cell lines are shown for these studies to ensure that the results are due to expression of ER $\beta$ and not clonal variation. 
Induction of cell proliferation following estrogen treatment was identical between parental and ER $\beta$ expressing MCF7 cells (Figure 5). Similar to the gene expression data presented in Figure 4, low concentrations of endoxifen (20 to $40 \mathrm{nM}$ ) significantly inhibited estrogen induced growth of MCF7-ER $\beta$ cells but not parental MCF7 cells (Figure 5). In fact, 100 to $1,000 \mathrm{nM}$ concentrations of endoxifen were required to completely block estrogen induced growth of parental MCF7 cells while 20 to $40 \mathrm{nM}$ endoxifen concentrations were essentially as effective in ER $\beta$ positive cells (Figure 5). These studies confirm that ER $\beta$ expression sensitizes breast cancer cells to the anti-estrogenic actions of endoxifen.

\section{ER $\beta$ expression results in unique gene expression} patterns following estrogen and endoxifen exposure In an effort to determine the mechanisms by which low concentrations of endoxifen effectively block estrogen induced growth of ER $\beta$ expressing cells, but not parental MCF7 cells, the global gene expression profiles were examined in these two cell lines following treatment with estrogen alone or estrogen plus $40 \mathrm{nM}$ endoxifen. The $40 \mathrm{nM}$ endoxifen concentration was chosen since it resulted in the largest differences in proliferation rates between parental and MCF7-ER $\beta$ cells. Microarray analysis revealed that estrogen treatment significantly altered the expression of 461 genes in parental MCF7 cells using a fold change cutoff of 1.5 (Figure 6A). Of these genes, 211 exhibited increased expression while 251 exhibited decreased expression. Nearly 2.5 times as many genes were determined to be significantly regulated in the MCF7-ER $\beta$ cell line using the same statistical and fold change cutoff parameters. Specifically, 1,137 genes were differentially expressed following estrogen treatment of which 604 were increased and 535 were decreased (Figure 6A). Comparison of these two data sets revealed that 381 (31\%) were commonly regulated between the two cell lines, while only 80 (7\%) were unique to the parental cell line and 756 (62\%) were unique to the ER $\beta$ line (Figure 6A). A list of these genes and their detected fold changes is provided in Additional file 3. Two genes exhibiting increased expression and two genes exhibiting decreased expression in response to estrogen treatment were randomly selected for each cell line and confirmed by real-time PCR. The relative expression levels for these genes as determined by both microarray and real-time PCR are shown in Figure 6B.

We next compared the microarray results of parental and MCF7-ER $\beta$ expressing cells treated with estrogen plus $40 \mathrm{nM}$ endoxifen to estrogen treatment alone. Using the same selection criteria as above, significantly fewer genes were determined to be regulated by this dose of endoxifen. In the parental cell line, the expression levels of 75 genes were altered by at least 1.5 -fold by the addition of endoxifen of which 44 were increased and 31 were decreased (Figure 6C). Similar results were observed in the MCF7-ER $\beta$ cell line in that a total of 78 genes were differentially regulated in response to endoxifen with 37 exhibiting increased expression and

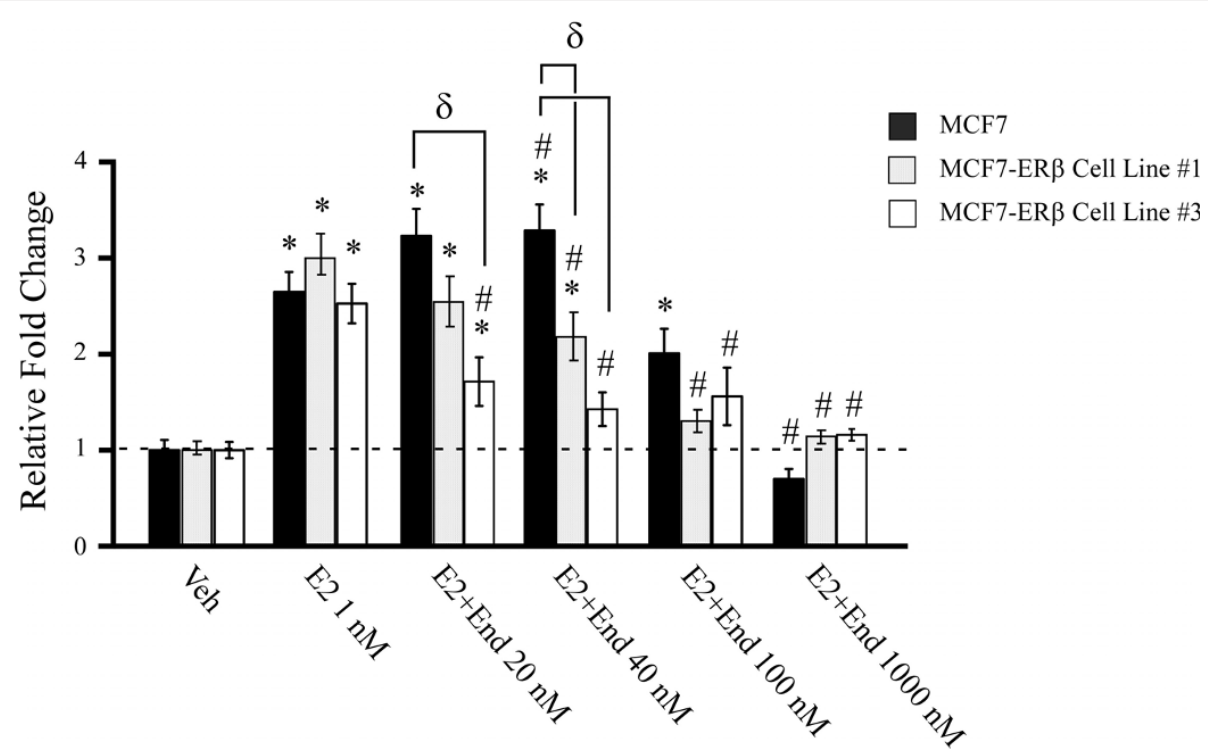

Figure 5 Low concentrations of endoxifen inhibit estrogen induced proliferation of MCF7-ER $\beta$ cells. Parental and MCF7-ER $\beta$ cells (cell lines \#1 and \#3) were treated as indicated for eight days and cell proliferation rates were analyzed. Graphs depict fold change from vehicle treated cells. ${ }^{*}$ denotes significance at the $P<0.05$ level (ANOVA) compared to vehicle controls, \# compared to estrogen treated cells and $\delta$ for a given treatment between the two cell lines. 


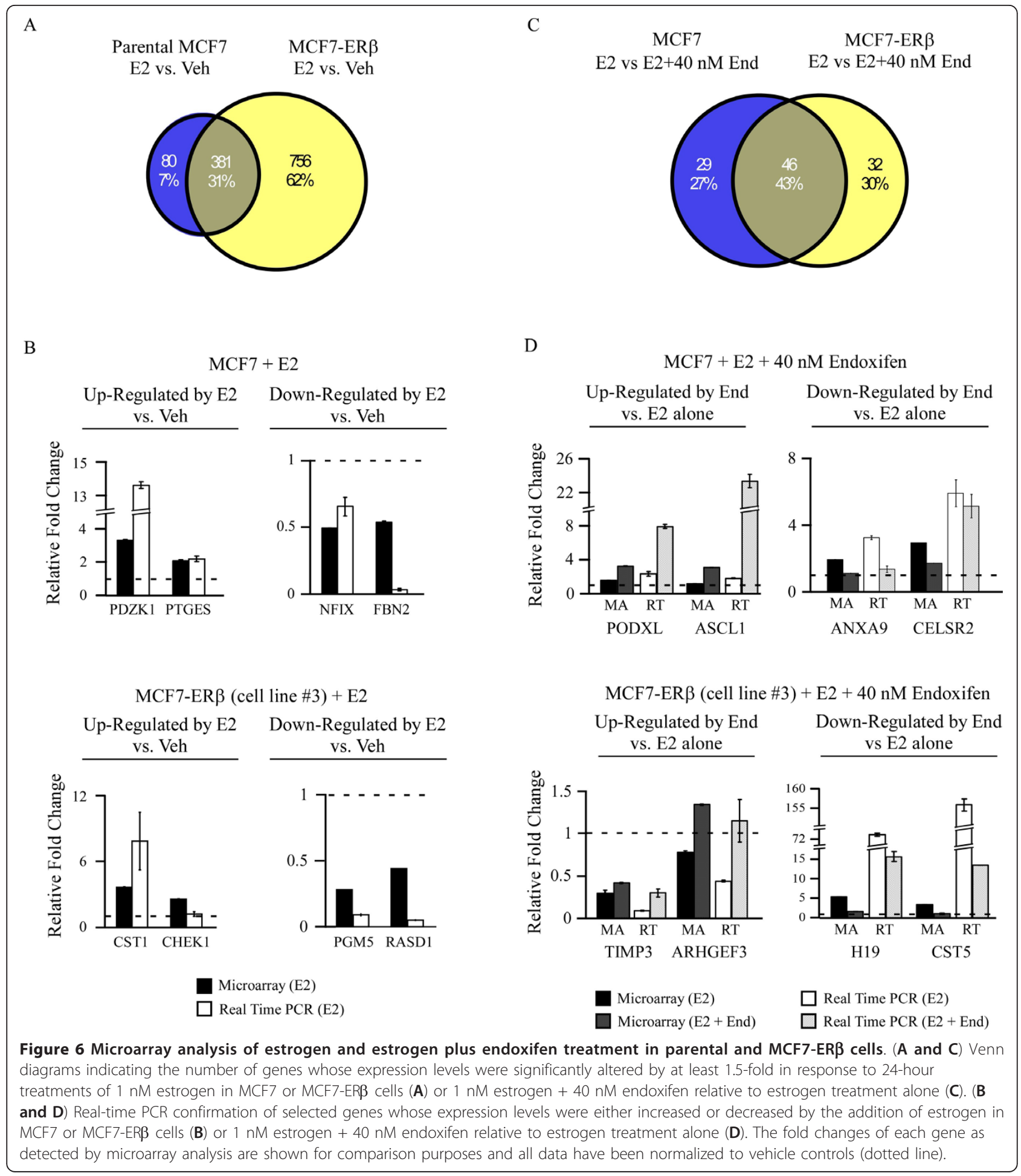

41 exhibiting decreased expression (Figure 6C). Comparison of these two data sets indicated that 46 genes (43\%) were commonly regulated in both cell lines while 29 (27\%) were unique to the parental cells and $32(30 \%)$ were unique to the ER $\beta$ expressing cells (Figure 6C). A list of these genes and their detected fold changes is provided in Additional file 4. As above, two genes exhibiting increased expression and two genes exhibiting decreased expression in response to endoxifen treatment were randomly selected for each cell line and confirmed by real-time PCR. The relative expression levels of these genes as determined by both microarray and real-time 
PCR following estrogen treatment alone and estrogen plus endoxifen are shown in Figure 6D.

As with the proliferation data, to ensure that the detected gene expression differences in response to estrogen and endoxifen were truly due to the presence of ER $\beta$ and not a result of clonal variation, the confirmation of gene expression studies were also carried out in a second ER $\beta$ cell line (\#1). These results revealed the same trends in gene expression elicited in response to both estrogen and endoxifen (Figure 7A, B) and suggest that these differences are in fact a result of ER $\beta$ expression and not due to clonal variation between cell lines.

\section{Pathway analysis identifies specific biological processes that are uniquely regulated by endoxifen in MCF7-ER $\beta$ cells}

Pathway analysis was performed on the gene lists generated from both the parental and MCF7-ER $\beta$ cells treated with estrogen plus $40 \mathrm{nM}$ endoxifen relative to estrogen alone. For this analysis, all genes whose expression levels were significantly altered $(P<0.05)$ by the addition of endoxifen and whose fold changes were $>2$ standard deviations away from all genes kept in the analysis (approximately 1.2-fold) were utilized. This analysis identified 13 pathways in the parental cell line and 12 pathways in the MCF7-ER $\beta$ cell line which had significant enrichment of genes based on a $P<0.05$. While none of these pathways passed a false discovery rate threshold of 0.25 after adjusting for multiple comparisons likely due to relatively small numbers of genes, it is interesting to note that biological pathways involving $E R \alpha$ cell cycle regulation and cell migration were only affected by endoxifen in breast cancer cells expressing ER $\beta$ (Table 1). As with the gene expression data, many of the identified pathways were unique to either the parental or ER $\beta$ expressing cell lines (identified by an asterisk) lending further support to the differential effects of endoxifen as a result of ER isoform specific expression (Table 1).

\section{Discussion}

\section{Endocrine sensitive breast cancer}

The large majority of breast cancer patients display tumors that are estrogen dependent based on the expression of ER $\alpha$. Deprivation of estrogen signaling, most commonly through the use of tamoxifen in the adjuvant setting, typically results in tumor regression. However, the use of ER $\alpha$ alone as an indicator of responsiveness to anti-estrogens is far from perfect as about one-half of ER $\alpha$ positive tumors do not respond to tamoxifen therapy and about $10 \%$ of $E R \alpha$ negative tumors do respond. These studies demonstrate that other estrogen and anti-estrogen receptors and/or signaling pathways may be involved in mediating the responsiveness of endocrine sensitive tumors to hormonal agents. Following the discovery of ER $\beta$, investigators have sought to uncover the role that this protein may play in mediating breast cancer progression and treatment. Here, we demonstrate that expression of ER $\beta$ in $E R \alpha$ positive MCF7 cells significantly enhances the antiestrogenic effects of endoxifen. This study provides evidence that endoxifen stabilizes ER $\beta$ protein levels and induces $E R \alpha / \beta$ heterodimer formation which results in differential gene expression patterns. Perhaps most importantly, our studies reveal that even low concentrations of endoxifen, mimicking that of poor and intermediate CYP2D6 metabolizers, results in repression of estrogen induced breast cancer proliferation in cells expressing ER $\beta$, but not in those that express only ER $\alpha$.

\section{Role of ER $\beta$ in breast cancer}

ER $\beta$ is known to be expressed in normal breast epithelial cells and several studies have demonstrated that ER $\beta$ expression levels are suppressed in many breast cancers [51-54]. However, re-expression of ER $\beta$ in ER negative breast cancer cells has been shown to reduce both basal and estrogen induced proliferation rates $[21,24,25]$. Expression of ER $\beta$ in ER $\alpha$ positive breast cancer cells also results in suppression of proliferation following estrogen exposure [26-28]. Furthermore, ER $\beta$ expression has been shown to increase the effectiveness of high concentrations of SERMs such as 4HT, raloxifen and fulvestrant $[28,55]$ in vitro. While the latter studies did not analyze endoxifen, nor did they utilize clinically relevant concentrations of $4 \mathrm{HT}$ (plasma concentrations are less than $10 \mathrm{nM}$ in patients receiving $20 \mathrm{mg} /$ day), they do further implicate a role for ER $\beta$ in mediating antiestrogenic activities.

It is possible that the increased effectiveness of endoxifen in ER $\beta$ expressing MCF7 cells is related to the molecular actions of $E R \alpha / \beta$ heterodimers since we demonstrate that heterodimer formation is induced in a concentration dependent manner following endoxifen exposure. Indeed, the global gene expression changes induced by estrogen and anti-estrogens are known to be different in cells expressing both estrogen receptors relative to cells expressing only ER $\alpha$ or ER $\beta[20,21,56]$. The results of the present study also demonstrate that both estrogen and endoxifen regulate unique subsets of genes in MCF7 cells expressing both receptors relative to cells expressing ER $\alpha$ alone. Biological pathway analysis of endoxifen regulated genes revealed that the majority of altered pathways are unique to either the parental or ER $\beta$ expressing cell lines. Pathways involving ER $\alpha$ mediated cell cycle regulation and cell migration were only affected in the presence of ER $\beta$ suggesting that the increased effectiveness of endoxifen may be through the inhibition of ER $\alpha$ activity by ER $\beta$. 


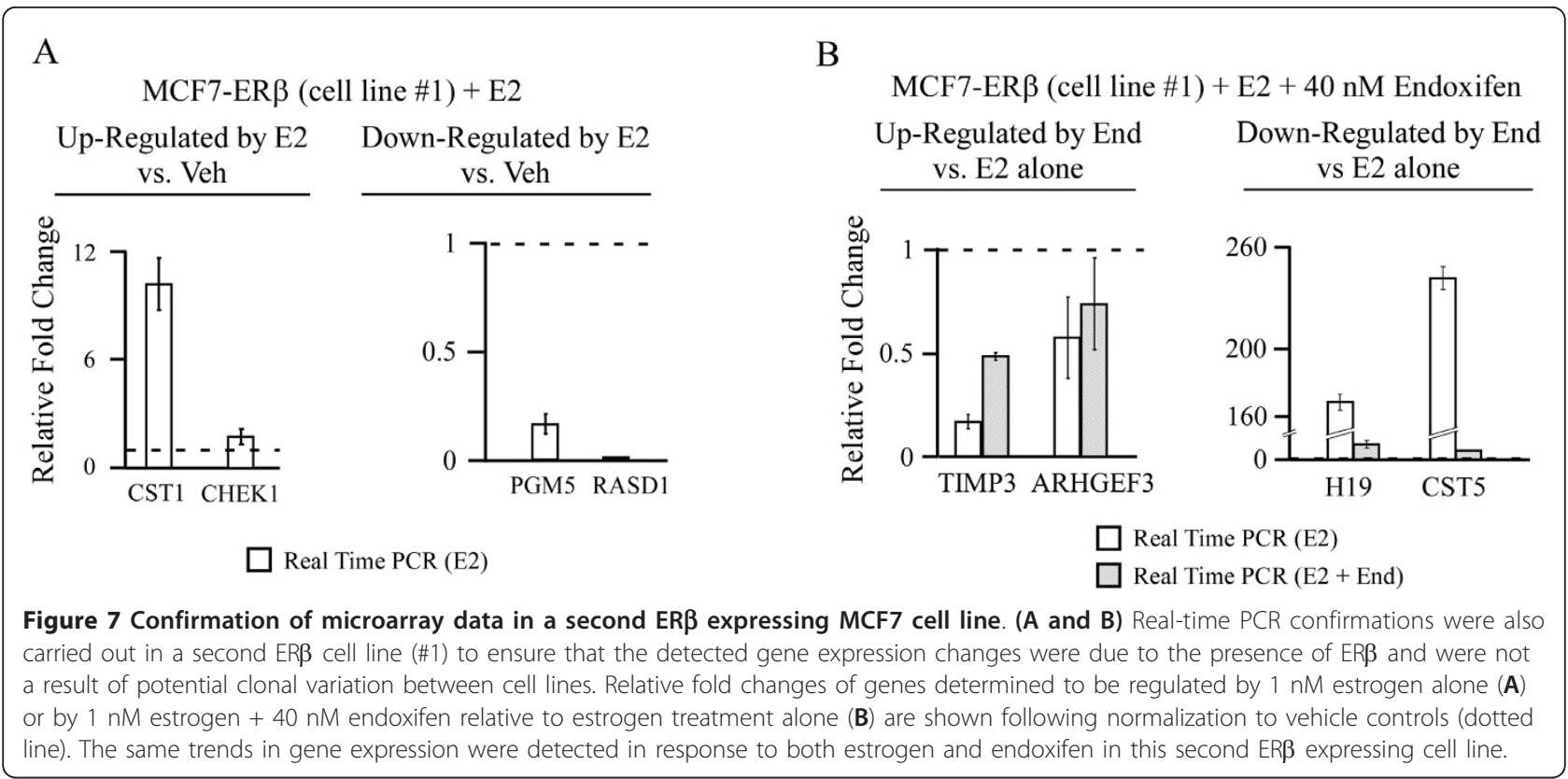

Table 1 Biological pathways regulated by estrogen plus $40 \mathrm{nM}$ endoxifen relative to estrogen treatment alone

\begin{tabular}{|c|c|c|c|}
\hline \multirow[b]{2}{*}{ Pathway \# } & \multicolumn{3}{|l|}{ MCF7 Parental Cells } \\
\hline & Pathway Name & $P$-Value & \# Genes \\
\hline $1^{*}$ & Immune response_Antiviral actions of Interferons & 0.0008 & $6 / 20$ \\
\hline $2^{*}$ & Immune response_IFN gamma signaling pathway & 0.0177 & $6 / 36$ \\
\hline 3 & Regulation of lipid metabolism_Regulation of fatty acid synthase activity & 0.0182 & $3 / 10$ \\
\hline 4 & Neurodisease_Parkin disorder under Parkinson disease & 0.0191 & $4 / 18$ \\
\hline $5^{*}$ & Regulation of lipid metabolism_Regulation of acetyl-CoA carboxylase 1 & 0.0195 & $2 / 4$ \\
\hline $6^{*}$ & Cholesterol Biosynthesis & 0.0276 & $4 / 20$ \\
\hline $7^{*}$ & Niacin-HDL metabolism & 0.0305 & $3 / 12$ \\
\hline $8^{*}$ & Cytoskeleton remodeling_Thyroliberin in cytoskeleton remodeling & 0.0305 & $3 / 12$ \\
\hline 9 & CFTR-dependent regulation of ion channels in Airway Epithelium & 0.0326 & $4 / 21$ \\
\hline 10 & Immune response_IL-27 signaling pathway & 0.0380 & $3 / 13$ \\
\hline $11^{*}$ & Development_A1 receptor signaling & 0.0440 & $4 / 23$ \\
\hline $12^{*}$ & Neurophysiological process_PGE2-induced pain processing & 0.0450 & $2 / 6$ \\
\hline \multirow[t]{2}{*}{$13^{*}$} & Immune response_Th1 and Th2 cell differentiation & 0.0463 & $3 / 14$ \\
\hline & MCF7-ER $\beta$ Cells & & \\
\hline $1^{*}$ & wtCFTR and deltaF508 traffic/Membrane expression (norm and CF) & 0.0026 & $5 / 16$ \\
\hline 2 & Regulation of lipid metabolism_Regulation of fatty acid synthase activity & 0.0026 & $4 / 10$ \\
\hline 3 & Immune response_IL-27 signaling pathway & 0.0077 & $4 / 13$ \\
\hline $4^{*}$ & Blood coagulation_Blood coagulation & 0.0132 & $4 / 15$ \\
\hline $5^{*}$ & Cell cycle_ER $\alpha$ regulation of G1/S transition & 0.0167 & $5 / 24$ \\
\hline $6^{*}$ & Globo-(isoglobo) series GSL Metabolism & 0.0228 & $3 / 10$ \\
\hline 7 & Neurodisease_Parkin disorder under Parkinson disease & 0.0254 & $4 / 18$ \\
\hline $8^{*}$ & ER $\alpha$ action on cytoskeleton remodeling and cell migration & 0.0299 & $3 / 11$ \\
\hline $9^{*}$ & Transcription_Ligand-Dependent Transcription of Retinoid-Target genes & 0.0306 & $4 / 19$ \\
\hline $10^{*}$ & $\mathrm{ENaC}$ regulation in airways (normal and $\mathrm{CF}$ ) & 0.0364 & $4 / 20$ \\
\hline 11 & CFTR-dependent regulation of ion channels in Airway Epithelium & 0.0427 & $4 / 21$ \\
\hline $12^{*}$ & wtCFTR and delta508-CFTR traffic/Generic schema (norm and CF) & 0.0463 & $5 / 31$ \\
\hline
\end{tabular}




\section{Compounds which induce ER heterodimer formation as therapeutic drugs}

The ability of specific compounds to induce ER heterodimer formation is of significant importance since these two receptors are often expressed in the same cells of many different tissues, including breast tumors, and since different dimer pairs have distinct genomic targets [57]. Of particular interest is the observation that genistein, a compound originally thought to contribute to decreased breast cancer risk, specifically induces ER $\alpha$ homodimerization and transcriptional activity [58]. This observation correlates well with more recent studies demonstrating that genistein is not effective in the prevention of breast cancer $[59,60]$. Conversely, liquiritigenin is a highly selective ER $\beta$ agonist which does not stimulate ER $\alpha$ positive tumor formation [61] or ER $\alpha$ homodimerization [58] suggesting that it may serve as a suppressor of proliferation in ER $\beta$ expressing cells. The summation of these studies indicates that the identification of compounds which can specifically induce and/or activate ER $\alpha / \beta$ heterodimers or ER $\beta$ homodimers may have therapeutic potential. Endoxifen may serve as such a compound since it stabilizes ER $\beta$ protein levels and induces heterodimer formation in cells expressing both ER isoforms while simultaneously degrading ER $\alpha$ protein in ER $\beta$ negative cells [16].

\section{Impact of ER $\beta$ positivity and increased endoxifen effectiveness}

The identification of increased endoxifen effectiveness as an anti-estrogenic agent in the setting of ER $\beta$ is of significant clinical importance due to the fact that ER $\beta$ expression is reported to exist in approximately $75 \%$ of invasive breast cancers $[33,36,37,42,62-64]$ and in a subset of tumors which are ER $\alpha$ negative $[41,45,65]$. The majority of reports suggest that the presence of ER $\beta$ in breast tumors correlates with improved rates of recurrence, disease-free survival and overall survival [29-38]; however, others indicate little correlation [39-41]. A few recent clinical studies have revealed that ER $\beta$ increases the effectiveness of tamoxifen therapy for breast cancer [44-46]. Given that endoxifen is being developed for the treatment of ER positive breast cancer, future studies should evaluate the association between ER $\beta$ expression and the activity of endoxifen in human breast tumors.

\section{Conclusions}

The present data indicate that ER $\beta$ enhances the antiestrogenic actions of endoxifen in breast cancer cells. These data correlate well with the clinical studies demonstrating increased benefit from tamoxifen therapy in those patients whose tumors are ER $\beta$ positive and suggest that this benefit may be through the actions of endoxifen. The ability of low endoxifen concentrations to significantly inhibit estrogen induced gene expression and proliferation in ER $\beta$ expressing breast cancer cells also suggests that benefits from tamoxifen therapy may still be observed in patients characterized as poor metabolizers based on CYP2D6 genotype if their tumors are ER $\beta$ positive. Finally, these studies highlight the need to further investigate the role of ER $\beta$ in breast cancer, both as a prognostic and predictive factor, and lend additional support to the development of endoxifen as a novel therapeutic for the treatment of endocrine sensitive breast tumors.

\section{Additional material}

Additional file 1: Table indicating the sequences of primers used throughout this manuscript.

Additional file 2: Confirmation of ER $\beta$ negativity in parental MCF7 cells. (A) Real-time PCR and (B) Western blot analysis demonstrating that ER $\beta$ expression at both the mRNA and protein level is undetectable in parental MCF7 cells. These data are shown in comparison to one of the ERß-expressing clonal cell lines (cell line \#3).

Additional file 3: Table indicating the genes determined to be significantly regulated by $1 \mathrm{nM}$ estrogen in parental and ER $\beta$ expressing MCF7 cells.

Additional file 4: Table indicating the genes determined to be significantly regulated by $1 \mathrm{nM}$ estrogen $+40 \mathrm{nM}$ Endoxifen in parental and ER $\beta$ expressing MCF7 cells.

\section{Abbreviations}

4HT: 4-hydroxy-tamoxifen; 17ß-estrodiol: estrogen; AA: antibiotic/antimycotic; CYP2D6: cytochrome P450 2D6; DMEM/F12: Dulbecco's Modified Eagle's Medium/F12; DPN: diarylpropionitrile; ER: estrogen receptor; ERa: estrogen receptor-alpha; ERR: estrogen receptor-beta; ERE: estrogen response element; FBS: fetal bovine serum; G418: geneticin; NCl: National Cancer Institute; NDT: N-desmethyl-tamoxifen; PPT: propyl pyrazole triol; RT-PCR: real-time polymerase chain reaction; SDS-PAGE: sodium dodecyl sulfate polyacrylamide gel electrophoresis; SERM: selective estrogen receptor modulator.

\section{Acknowledgements}

The authors would like to thank Elizabeth Bruinsma, Kenneth Peters, Kevin Pitel and Muzaffer Cicek for their excellent technical support and Jacquelyn House for her outstanding secretarial assistance. Additionally, we would like to thank the Mayo Clinic Advanced Genomic Technology Center Microarray Shared Resource for their invaluable contribution to this study. This work was supported by Susan G. Komen for the Cure KG100142 (JRH), a Breast Cancer Research Foundation grant (JNI and TCS), a generous gift from Bruce and Martha Atwater (TCS, JRH, MPG, JNI), a Breast Cancer SPORE (P50CA116201) Career Development Award (JRH) and the Mayo Foundation.

\section{Author details}

'Department of Biochemistry and Molecular Biology, Mayo Clinic, 200 1stStreet SW, Rochester, MN 55905, USA. ${ }^{2}$ Bioinformatics Core, Division of Biomedical Statistics and Informatics, Mayo Clinic, 200 1st Street SW, Rochester, MN 55905, USA. ${ }^{3}$ Department of Laboratory Medicine and Pathology, Mayo Clinic, 200 1st Street SW, Rochester, MN 55905, USA. ${ }^{4}$ Department of Oncology, Mayo Clinic, 200 1st Street SW, Rochester, MN 55905, USA.

\section{Authors' contributions}

$X W, M S, W L L, M P G, J N I, T C S$ and JRH conceived of the study, participated in its design and drafted the manuscript. XW, SBG, VN and JRH performed the laboratory experiments and analyzed the data. ZS performed the microarray 
and biological pathway analysis. All authors read and approved the final manuscript.

\section{Competing interests}

XW, MS, SBG, ZS, VN, WLL, TCS and JRH declare that they have no competing interests. MPG and JNI are named inventors (along with the Mayo (linic) in regard to non-provisional patent applications regarding tamoxifen and CYP2D6; the technology is not licensed, and no royalties have accrued.

Received: 18 August 2010 Revised: 4 February 2011

Accepted: 10 March 2011 Published: 10 March 2011

\section{References}

1. Crewe HK, Lennard MS, Tucker GT, Woods FR, Haddock RE: The effect of selective serotonin re-uptake inhibitors on cytochrome P4502D6 (CYP2D6) activity in human liver microsomes. 1992. Br J Clin Pharmacol 2004, 58:S744-747, discussion 748-750.

2. Desta Z, Ward BA, Soukhova NV, Flockhart DA: Comprehensive evaluation of tamoxifen sequential biotransformation by the human cytochrome P450 system in vitro: prominent roles for CYP3A and CYP2D6. $J$ Pharmacol Exp Ther 2004, 310:1062-1075.

3. Stearns V, Johnson MD, Rae JM, Morocho A, Novielli A, Bhargava P, Hayes DF, Desta Z, Flockhart DA: Active tamoxifen metabolite plasma concentrations after coadministration of tamoxifen and the selective serotonin reuptake inhibitor paroxetine. J Natl Cancer Inst 2003, 95:1758-1764

4. Borges S, Desta Z, Li L, Skaar TC, Ward BA, Nguyen A, Jin Y, Storniolo AM, Nikoloff DM, Wu L, Hillman G, Hayes DF, Stearns V, Flockhart DA: Quantitative effect of CYP2D6 genotype and inhibitors on tamoxifen metabolism: implication for optimization of breast cancer treatment. Clin Pharmacol Ther 2006, 80:61-74.

5. Jin $Y$, Desta Z, Stearns V, Ward B, Ho H, Lee KH, Skaar T, Storniolo AM, Li L, Araba A, Blanchard R, Nguyen A, Ullmer L, Hayden J, Lemler S, Weinshilboum RM, Rae JM, Hayes DF, Flockhart DA: CYP2D6 genotype, antidepressant use, and tamoxifen metabolism during adjuvant breast cancer treatment. J Natl Cancer Inst 2005, 97:30-39.

6. Bijl MJ, van Schaik RH, Lammers LA, Hofman A, Vulto AG, van Gelder T, Stricker BH, Visser LE: The CYP2D6*4 polymorphism affects breast cancer survival in tamoxifen users. Breast Cancer Res Treat 2009, 118:125-130

7. Goetz MP, Knox SK, Suman VJ, Rae JM, Safgren SL, Ames MM, Visscher DW, Reynolds C, Couch FJ, Lingle WL, Weinshilboum RM, Fritcher EG, Nibbe AM, Desta Z, Nguyen A, Flockhart DA, Perez EA, Ingle JN: The impact of cytochrome P450 2D6 metabolism in women receiving adjuvant tamoxifen. Breast Cancer Res Treat 2007, 101:113-121.

8. Goetz MP, Rae JM, Suman VJ, Safgren SL, Ames MM, Visscher DW, Reynolds C, Couch FJ, Lingle WL, Flockhart DA, Desta Z, Perez EA, Ingle JN: Pharmacogenetics of tamoxifen biotransformation is associated with clinical outcomes of efficacy and hot flashes. J Clin Oncol 2005, 23:9312-9318.

9. Kiyotani K, Mushiroda T, Sasa M, Bando Y, Sumitomo I, Hosono N, Kubo M Nakamura $Y$, Zembutsu H: Impact of CYP2D6*10 on recurrence-free survival in breast cancer patients receiving adjuvant tamoxifen therapy. Cancer Sci 2008, 99:995-999.

10. Newman WG, Hadfield KD, Latif A, Roberts SA, Shenton A, McHague C, Lalloo F, Howell S, Evans DG: Impaired tamoxifen metabolism reduces survival in familial breast cancer patients. Clin Cancer Res 2008, 14:5913-5918.

11. Nowell SA, Ahn J, Rae JM, Scheys JO, Trovato A, Sweeney C, MacLeod SL, Kadlubar FF, Ambrosone CB: Association of genetic variation in tamoxifen-metabolizing enzymes with overall survival and recurrence of disease in breast cancer patients. Breast Cancer Res Treat 2005, 91:249-258.

12. Schroth W, Antoniadou L, Fritz P, Schwab M, Muerdter T, Zanger UM, Simon W, Eichelbaum M, Brauch H: Breast cancer treatment outcome with adjuvant tamoxifen relative to patient CYP2D6 and CYP2C19 genotypes. J Clin Oncol 2007, 25:5187-5193.

13. Wegman P, Elingarami S, Carstensen J, Stal O, Nordenskjold B, Wingren S: Genetic variants of CYP3A5, CYP2D6, SULT1A1, UGT2B15 and tamoxifen response in postmenopausal patients with breast cancer. Breast Cancer Res 2007, 9:R7.
14. Xu Y, Sun Y, Yao L, Shi L, Wu Y, Ouyang T, Li J, Wang T, Fan Z, Fan T, Lin B, He L, Li P, Xie Y: Association between CYP2D6 ${ }^{*} 10$ genotype and survival of breast cancer patients receiving tamoxifen treatment. Ann Oncol 2008, 19:1423-1429.

15. Ramon y Cajal T, Altes A, Pare L, del Rio E, Alonso C, Barnadas A, Baiget M: Impact of CYP2D6 polymorphisms in tamoxifen adjuvant breast cancer treatment. Breast Cancer Res Treat 119:33-38.

16. Wu X, Hawse JR, Subramaniam M, Goetz MP, Ingle JN, Spelsberg TC: The tamoxifen metabolite, endoxifen, is a potent antiestrogen that targets estrogen receptor alpha for degradation in breast cancer cells. Cancer Res 2009, 69:1722-1727.

17. Waters KM, Rickard DJ, Riggs BL, Khosla S, Katzenellenbogen JA, Katzenellenbogen BS, Moore J, Spelsberg TC: Estrogen regulation of human osteoblast function is determined by the stage of differentiation and the estrogen receptor isoform. J Cell Biochem 2001, 83:448-462.

18. Rickard DJ, Waters KM, Ruesink TJ, Khosla S, Katzenellenbogen JA, Katzenellenbogen BS, Riggs BL, Spelsberg TC: Estrogen receptor isoformspecific induction of progesterone receptors in human osteoblasts. $J$ Bone Miner Res 2002, 17:580-592.

19. Monroe DG, Getz BJ, Johnsen SA, Riggs BL, Khosla S, Spelsberg TC: Estrogen receptor isoform-specific regulation of endogenous gene expression in human osteoblastic cell lines expressing either ERalpha or ERbeta. J Cell Biochem 2003, 90:315-326.

20. Monroe DG, Secreto FJ, Subramaniam M, Getz BJ, Khosla S, Spelsberg TC: Estrogen receptor alpha and beta heterodimers exert unique effects on estrogen- and tamoxifen-dependent gene expression in human U2OS osteosarcoma cells. Mol Endocrinol 2005, 19:1555-1568.

21. Secreto FJ, Monroe DG, Dutta S, Ingle JN, Spelsberg TC: Estrogen receptor alpha/beta isoforms, but not betacx, modulate unique patterns of gene expression and cell proliferation in Hs578T cells. J Cell Biochem 2007, 101:1125-1147.

22. Kian Tee M, Rogatsky I, Tzagarakis-Foster C, Cvoro A, An J, Christy RJ, Yamamoto KR, Leitman DC: Estradiol and selective estrogen receptor modulators differentially regulate target genes with estrogen receptors alpha and beta. Mol Biol Cell 2004, 15:1262-1272.

23. Stossi F, Barnett DH, Frasor J, Komm B, Lyttle CR, Katzenellenbogen BS: Transcriptional profiling of estrogen-regulated gene expression via estrogen receptor (ER) alpha or ERbeta in human osteosarcoma cells: distinct and common target genes for these receptors. Endocrinology 2004, 145:3473-3486.

24. Lazennec G, Bresson D, Lucas A, Chauveau C, Vignon F: ER beta inhibits proliferation and invasion of breast cancer cells. Endocrinology 2001 142:4120-4130.

25. Thomas CG, Strom A, Lindberg K, Gustafsson JA: Estrogen receptor beta decreases survival of p53-defective cancer cells after DNA damage by impairing G(2)/M checkpoint signaling. Breast Cancer Res Treat 2010.

26. Sotoca $A M$, van den Berg $H$, Vervoort J, van der Saag P, Strom A, Gustafsson JA, Rietjens I, Murk AJ: Influence of cellular ERalpha/ERbeta ratio on the ERalpha-agonist induced proliferation of human T47 D breast cancer cells. Toxicol Sci 2008, 105:303-311.

27. Paruthiyil S, Parmar H, Kerekatte V, Cunha GR, Firestone GL, Leitman DC: Estrogen receptor beta inhibits human breast cancer cell proliferation and tumor formation by causing a G2 cell cycle arrest. Cancer Res 2004, 64:423-428.

28. Strom A, Hartman J, Foster JS, Kietz S, Wimalasena J, Gustafsson JA: Estrogen receptor beta inhibits 17 beta-estradiol-stimulated proliferation of the breast cancer cell line T47D. Proc Natl Acad Sci USA 2004, 101:1566-1571.

29. Esslimani-Sahla M, Simony-Lafontaine J, Kramar A, Lavaill R, Mollevi C, Warner M, Gustafsson JA, Rochefort H: Estrogen receptor beta (ER beta) level but not its ER beta cx variant helps to predict tamoxifen resistance in breast cancer. Clin Cancer Res 2004, 10:5769-5776.

30. Fleming FJ, Hill AD, McDermott EW, O'Higgins NJ, Young LS: Differential recruitment of coregulator proteins steroid receptor coactivator-1 and silencing mediator for retinoid and thyroid receptors to the estrogen receptor-estrogen response element by beta-estradiol and 4hydroxytamoxifen in human breast cancer. J Clin Endocrinol Metab 2004, 89:375-383.

31. Hopp TA, Weiss HL, Parra IS, Cui Y, Osborne CK, Fuqua SA: Low levels of estrogen receptor beta protein predict resistance to tamoxifen therapy in breast cancer. Clin Cancer Res 2004, 10:7490-7499. 
32. Iwase $H$, Zhang Z, Omoto $Y$, Sugiura H, Yamashita H, Toyama T, Iwata H, Kobayashi S: Clinical significance of the expression of estrogen receptors alpha and beta for endocrine therapy of breast cancer. Cancer Chemother Pharmacol 2003, 52(Suppl 1):S34-38.

33. Mann S, Laucirica R, Carlson N, Younes PS, Ali N, Younes A, Li Y, Younes M: Estrogen receptor beta expression in invasive breast cancer. Hum Pathol 2001, 32:113-118.

34. Murphy LC, Leygue E, Niu Y, Snell L, Ho SM, Watson PH: Relationship of coregulator and oestrogen receptor isoform expression to de novo tamoxifen resistance in human breast cancer. Br J Cancer 2002, 87:1411-1416.

35. Myers E, Fleming FJ, Crotty TB, Kelly G, McDermott EW, O'Higgins N J, Hill AD, Young LS: Inverse relationship between ER-beta and SRC-1 predicts outcome in endocrine-resistant breast cancer. Br J Cancer 2004, 91:1687-1693

36. Nakopoulou L, Lazaris AC, Panayotopoulou EG, Giannopoulou I, Givalos N, Markaki S, Keramopoulos A: The favourable prognostic value of oestrogen receptor beta immunohistochemical expression in breast cancer. J Clin Pathol 2004, 57:523-528.

37. Omoto $Y$, Inoue S, Ogawa S, Toyama T, Yamashita H, Muramatsu M, Kobayashi S, Iwase H: Clinical value of the wild-type estrogen receptor beta expression in breast cancer. Cancer Lett 2001, 163:207-212.

38. Sugiura H, Toyama T, Hara $Y$, Zhang $Z$, Kobayashi S, Fujii $Y$, Iwase $H$, Yamashita $H$ : Expression of estrogen receptor beta wild-type and its variant ERbetacx/beta2 is correlated with better prognosis in breast cancer. Jpn J Clin Oncol 2007, 37:820-828.

39. Miller WR, Anderson TJ, Dixon JM, Saunders PT: Oestrogen receptor beta and neoadjuvant therapy with tamoxifen: prediction of response and effects of treatment. Br J Cancer 2006, 94:1333-1338.

40. O'Neill PA, Davies MP, Shaaban AM, Innes H, Torevell A, Sibson DR, Foster CS: Wild-type oestrogen receptor beta (ERbeta1) mRNA and protein expression in Tamoxifen-treated post-menopausal breast cancers. Br J Cancer 2004, 91:1694-1702.

41. Skliris GP, Leygue E, Curtis-Snell L, Watson PH, Murphy LC: Expression of oestrogen receptor-beta in oestrogen receptor-alpha negative human breast tumours. Br J Cancer 2006, 95:616-626.

42. Jensen EV, Cheng G, Palmieri C, Saji S, Makela S, Van Noorden S, Wahlstrom T, Warner M, Coombes RC, Gustafsson JA: Estrogen receptors and proliferation markers in primary and recurrent breast cancer. Proc Natl Acad Sci USA 2001, 98:15197-15202.

43. Speirs V, Parkes AT, Kerin MJ, Walton DS, Carleton PJ, Fox JN, Atkin SL: Coexpression of estrogen receptor alpha and beta: poor prognostic factors in human breast cancer? Cancer Res 1999, 59:525-528.

44. Honma N, Horii R, Iwase T, Saji S, Younes M, Takubo K, Matsuura M, Ito Y, Akiyama F, Sakamoto G: Clinical importance of estrogen receptor-beta evaluation in breast cancer patients treated with adjuvant tamoxifen therapy. J Clin Oncol 2008, 26:3727-3734.

45. Poola I, Fuqua SA, De Witty RL, Abraham J, Marshallack JJ, Liu A: Estrogen receptor alpha-negative breast cancer tissues express significant levels of estrogen-independent transcription factors, ERbeta1 and ERbeta5: potential molecular targets for chemoprevention. Clin Cancer Res 2005, 11:7579-7585

46. Shaaban AM, Green AR, Karthik S, Alizadeh Y, Hughes TA, Harkins L, Ellis IO, Robertson JF, Paish EC, Saunders PT, Groome NP, Speirs V: Nuclear and cytoplasmic expression of ERbeta1, ERbeta2, and ERbeta5 identifies distinct prognostic outcome for breast cancer patients. Clin Cancer Res 2008, 14:5228-5235.

47. Primer3 Input (v.0.4.0). [http://frodo.wi.mit.edu/primer3/].

48. Ballman KV, Grill DE, Oberg AL, Therneau TM: Faster cyclic loess: normalizing RNA arrays via linear models. Bioinformatics 2004, 20:2778-2786.

49. Gene Expression Omnibus (GEO). [http://www.ncbi.nlm.nih.gov/geo/]

50. Meyers MJ, Sun J, Carlson KE, Marriner GA, Katzenellenbogen BS, Katzenellenbogen JA: Estrogen receptor-beta potency-selective ligands: structure-activity relationship studies of diarylpropionitriles and their acetylene and polar analogues. J Med Chem 2001, 44:4230-4251.

51. Iwao K, Miyoshi Y, Egawa C, Ikeda N, Noguchi S: Quantitative analysis of estrogen receptor-beta mRNA and its variants in human breast cancers. Int J Cancer 2000, 88:733-736.
52. Leygue E, Dotzlaw $H$, Watson PH, Murphy LC: Altered estrogen receptor alpha and beta messenger RNA expression during human breast tumorigenesis. Cancer Res 1998, 58:3197-3201.

53. Leygue $\mathrm{E}$, Dotzlaw $\mathrm{H}$, Watson PH, Murphy LC: Expression of estrogen receptor beta1, beta2, and beta5 messenger RNAs in human breast tissue. Cancer Res 1999, 59:1175-1179.

54. Zhao C, Lam EW, Sunters A, Enmark E, De Bella MT, Coombes RC, Gustafsson JA, Dahlman-Wright K: Expression of estrogen receptor beta isoforms in normal breast epithelial cells and breast cancer: regulation by methylation. Oncogene 2003, 22:7600-7606.

55. Hodges-Gallagher L, Valentine CD, El Bader S, Kushner PJ: Estrogen receptor beta increases the efficacy of antiestrogens by effects on apoptosis and cell cycling in breast cancer cells. Breast Cancer Res Treat 2008, 109:241-250

56. Chang EC, Frasor J, Komm B, Katzenellenbogen BS: Impact of estrogen receptor beta on gene networks regulated by estrogen receptor alpha in breast cancer cells. Endocrinology 2006, 147:4831-4842.

57. Liu Y, Gao H, Marstrand TT, Strom A, Valen E, Sandelin A, Gustafsson JA, Dahlman-Wright K: The genome landscape of ERalpha- and ERbetabinding DNA regions. Proc Natl Acad Sci USA 2008, 105:2604-2609.

58. Powell $E, X u$ W: Intermolecular interactions identify ligand-selective activity of estrogen receptor alpha/beta dimers. Proc Natl Acad Sci USA 2008, 105:19012-19017

59. Ju YH, Allred KF, Allred CD, Helferich WG: Genistein stimulates growth of human breast cancer cells in a novel, postmenopausal animal model, with low plasma estradiol concentrations. Carcinogenesis 2006, 27:1292-1299.

60. Peeters PH, Keinan-Boker L, van der Schouw YT, Grobbee DE: Phytoestrogens and breast cancer risk. Review of the epidemiological evidence. Breast Cancer Res Treat 2003, 77:171-183.

61. Mersereau JE, Levy N, Staub RE, Baggett S, Zogovic T, Chow S, Ricke WA, Tagliaferri M, Cohen I, Bjeldanes LF, Leitman DC: Liquiritigenin is a plantderived highly selective estrogen receptor beta agonist. Mol Cell Endocrinol 2008, 283:49-57.

62. Saunders PT, Millar MR, Williams K, Macpherson S, Bayne C, O'Sullivan C, Anderson TJ, Groome NP, Miller WR: Expression of oestrogen receptor beta (ERbeta1) protein in human breast cancer biopsies. $\mathrm{Br} J$ Cancer 2002, 86:250-256.

63. Skliris GP, Carder PJ, Lansdown MR, Speirs V: Immunohistochemical detection of ERbeta in breast cancer: towards more detailed receptor profiling? Br J Cancer 2001, 84:1095-1098.

64. Fuqua SA, Schiff R, Parra I, Moore JT, Mohsin SK, Osborne CK, Clark GM, Allred DC: Estrogen receptor beta protein in human breast cancer: correlation with clinical tumor parameters. Cancer Res 2003, 63:2434-2439.

65. Skliris GP, Leygue E, Watson PH, Murphy LC: Estrogen receptor alpha negative breast cancer patients: estrogen receptor beta as a therapeutic target. J Steroid Biochem Mol Biol 2008, 109:1-10.

doi:10.1186/bcr2844

Cite this article as: Wu et al.: Estrogen receptor-beta sensitizes breast cancer cells to the anti-estrogenic actions of endoxifen. Breast Cancer Research 2011 13:R27.

\section{Submit your next manuscript to BioMed Central and take full advantage of:}

- Convenient online submission

- Thorough peer review

- No space constraints or color figure charges

- Immediate publication on acceptance

- Inclusion in PubMed, CAS, Scopus and Google Scholar

- Research which is freely available for redistribution

Submit your manuscript at www.biomedcentral.com/submit
C Biomed Central 